\title{
Literatura juvenil brasileira: a produção poética de Ricardo Azevedo
}

\author{
Juvenile brazilian literature: the poetic production \\ of Ricardo Azevedo
}

\section{Penha Lucilda de Souza Silvestre* \\ Alice Áurea Penteado Martha**}

Resumo: Neste artigo selecionamos e analisamos a produção poética do escritor, ilustrador e pesquisador Ricardo Azevedo, com o intuito de observarmos os aspectos temáticos. Referem-se aos seguintes títulos: Dezenove poemas desengonçados (1998), A casa de meu avô (1998), Meu material escolar (2000), O livro de papel (2001), Não existe dor gostosa (2003), Ninguém sabe o que é um poema (2005) e Feito bala perdida (2008). Tal leitura promove um repensar sobre a produção literária poética contemporânea, visto que se insere num contexto plural e globalizado. Além disso, procura compreender como se dá a constituição do objeto literário da poesia voltada ao público juvenil.

\begin{abstract}
In this article we selected and analyzed the poetic production of the writer, illustrator and researcher Ricardo Azevedo, in order to observe the recurring thematic aspects. The poetry of the writer consists of the following titles: Dezenove poemas desengonçados (1998), A casa de meu avô (1998), Meu material escolar (2000), O livro de papel (2001), Não existe dor gostosa (2003), Ninguém sabe o que é um poema (2005) and Feito bala perdida (2008). Such a reading promotes a rethinking of contemporary poetic literary production, since it operates in a pluralistic and globalized context. Furthermore, it means knowing how is the constitution of the literary object of poetry geared to a young audience.
\end{abstract}

Palavras-chave: Literatura juvenil, Poesia, Ricardo Azevedo, Aspectos temáticos. Keywords: Juvenile Literature, Poetry, Ricardo Azevedo, Thematic aspects.

\footnotetext{
* Universidade Estadual de Maringá- PR/UEM.

** Universidade Estadual de Maringá- PR/UEM.
} 


\section{Introdução}

O aspecto mais relevante da poesia é o fato de jogar com as palavras, ordenando-as de forma harmoniosa, revestindo-as de mistério, e de maneira tal que cada imagem passa a conter a solução de um enigma. Na construção poética, portanto, as palavras, ferramentas do poeta, não são usadas de modo habitual, metamorfoseiamse nas mãos do artesão, sofrem transformações que revelam a liberdade de criação. (MARTHA, 2012, p.46)

As produções literárias brasileiras infantis e juvenis vêm ganhando, ao longo do tempo, um espaço privilegiado na teoria e na crítica literárias. Isso se deve a escritores e ilustradores que garantem sua maturidade e sua qualidade artística, reconhecidas pela crítica e através de diversos prêmios conquistados por eles. É sabido que a pesquisa, nessa vertente, ainda é incipiente, sendo assim, verificamos a importância de um estudo voltado para a recepção crítica de obras literárias, não se reduzindo ao aspecto panorâmico.

Devido à grande demanda no mercado editorial de livros dirigidos aos públicos infantil e juvenil, é necessária uma análise cuidadosa para a distinção de obras que se manifestam sob dois vieses. De um lado, encontram-se aquelas que apenas apresentam um estereótipo, a repetição de fórmulas, contrapondo-se àquelas que privilegiam a inserção do leitor no mundo ficcional, instigando-o a imaginar e construir a sua própria subjetividade, definindo, assim, o valor emancipatório do texto literário. Em virtude dessa preocupação, estenderemos nossa discussão à produção poética do escritor brasileiro contemporâneo Ricardo Azevedo, visto que tem um número significativo de publicações e diversos livros premiados.

O interesse pela poesia atravessa o tempo cronológico e o histórico, transpõe a subjetividade e a palavra ganha forma, ritmo e rima, encontrando-se com o leitor que se depara com suas experiências intelectuais, artísticas e estéticas. 
Sendo assim, há evidências de que o texto poético refere-se a uma organização coerente, mediante a organização da palavra que se une a bagagem do leitor. Dessa maneira, a poesia trata-se de um processo comunicativo e exige a presença do receptor, que passa a ter uma visão diferente do mundo que o cerca ao adentrar-se nesse universo. O poeta, por sua vez, traduz o sentimento do mundo, nomeia e reconhece o seu espaço pela linguagem. Afinal, o "poeta é doador de sentimento" (BOSI, 2000, p. 163). Ele fala sobre os mais diversos estados psíquicos da alma, da condição social e política de seu tempo, das ideias filosóficas e ideológicas que perpassam os mais diversos grupos.

Assim, a poesia é indispensável ao homem, por levá-lo a atitudes reflexivas, à aquisição do saber e a um olhar crítico diante da complexidade do mundo, como também por fazê-lo experimentar momentos de profunda fruição. Desta maneira, assegura-se que a poesia trata-se de um instrumento consciente de revelação política, emocional e intelectual. O universo literário é levado à esfera do leitor e este, ao identificar-se com o eu-lírico, distancia-se de sua subjetividade, participa de uma outra vivência humana e, simultaneamente, pode incorporar ou negar a sua experiência.

Sabemos que a fantasia é fundamental para todas as pessoas, porque todos nós sonhamos, durante as horas de vigília ou não. A literatura, por sua vez, colabora para que o leitor possa vivenciar a ficção. Antonio Candido assinala que essa necessidade é inerente ao homem, independe da faixa etária ou formação intelectual. Para ele, a obra literária não pode "ser um mero apêndice da instrução moral e cívica" (CANDIDO, 1972, p. 805), ao contrário, deve ser um espaço onde o leitor possa experimentar as mais diversas experiências. Assegura que:

[...] a literatura aparece claramente como manifestação universal de todos os homens em todos os tempos. Não há povo e não há homem que possa viver sem ela, isto é, sem a possibilidade de entrar em contato com alguma espécie de fabulação. Assim como todos sonham todas as noites, ninguém é capaz de passar as vinte e quatro horas do dia sem alguns momentos de entrega ao universo fabulado. $\mathrm{O}$ sonho assegura a presença indispensável deste universo. E durante toda vigília a criação ficcional ou poética, que é a mola da literatura em todos os níveis e modalidades, está presente em cada um de nós, analfabeto ou erudito, como anedota, causo, história em quadrinho, noticiário policial, canção popular, moda de viola, samba carnavalesco. Ela se manifesta desde o devaneio amoroso 
ou econômico no ônibus até a atenção fixada na novela de televisão ou na leitura seguida de um romance. (CANDIDO, 1995, p. 235-286)

Sendo assim, a leitura do texto poético, além do entretenimento, permite ao leitor estabelecer e construir uma visão de mundo diferenciada a partir da organização das estrofes, versos, rimas e figuras de linguagem. Oferece ao leitor a possibilidade de transitar entre as metáforas que o constituem, tecido pelas palavras, sons e formas.

A fim de destacar e apresentar uma vertente multifacetada desse tipo de texto, atentamo-nos à produção poética direcionada ao público juvenil do escritor brasileiro Ricardo Azevedo. Para tanto, selecionamos e analisamos um corpus limitado, com o intuito de observarmos os aspectos temáticos recorrentes na produção poética. Vale ressaltar que Azevedo apresenta uma vasta produção literária, é ilustrador e pesquisador, como também já recebeu diversos prêmios de diversas instituições de premiação, o que evidencia um trabalho de qualidade estética e artística.

\section{A produção poética de Ricardo Azevedo}

Falar em literatura, como sabemos, significa falar em ficção e em discurso poético, mas muito mais do que isso. Significa abordar assuntos vistos, invariavelmente, do ponto de vista da subjetividade." (AZEVEDO, 2003, p. 79)

Ricardo Azevedo (São Paulo - 1949 -), escritor paulista, escreveu, ilustrou e organizou mais de oitenta livros por várias editoras, publicou ensaios e concedeu diversas entrevistas para revistas literárias, sendo assim, pode-se dizer que ele conta com uma produção significativa do ponto de vista quantitativo, como também dos aspectos artísticos e estéticos. Ele ganhou diversos prêmios literários importantes e suas obras foram traduzidas para inúmeras línguas. 
A produção poética de Azevedo é composta das seguintes obras: Dezenove poemas desengonçados (1998), A casa de meu avô (1998), Meu material escolar (2000), O livro de papel (2001), Não existe dor gostosa (2003), Ninguém sabe o que é um poema (2005) e Feito bala perdida (2008). Nessas produções, Azevedo mantém sua característica peculiar ao abordar temas que fazem parte do cotidiano e do universo da criança e do jovem. Para isso, ele desdobra a realidade próxima de seu leitor, sobretudo ao referir-se às emoções, sensações e sonhos, e ainda apresenta uma linguagem simples e bem elaborada, marcada por vários recursos poéticos, com rimas e ritmos leves e, ao mesmo tempo, pelas figuras sonoras e visuais. Vejamos um fragmento do texto A casa do meu avô (1998):

\author{
Ah como é boa essa vida \\ Na casa do meu avô! \\ Bem melhor do que sorvete \\ Mais gostosa que bombom \\ Que refresco, chocolate \\ Bolo, bala, caramelo. \\ Ah como é doce essa vida \\ Na casa do meu avô! (AZEVEDO, 1998) ${ }^{1}$
}

Notamos a presença de elementos simples e atrativos nestes versos: "Na casa do meu avô", "sorvete", "bombom", "refresco", "chocolate", "Bolo, bala, caramelo", típicos na obra do escritor e que fazem parte do cotidiano de qualquer criança ou adolescente. Na mesma obra, no texto "Lições do tio Nená", o autor desconstrói os padrões tradicionais de comportamento, outro aspecto importante que permeia a sua obra:
Mas se você for santinho
E andar todo penteadinho
Não falar palavra feia
For ordeiro e educado

\footnotetext{
${ }^{1} \mathrm{~A}$ obra $A$ casa do meu avô não apresenta numeração de páginas.
} 
Eu vou puxar a tua orelha

E te botar de pé

No canto de castigo

Vou te dar muita palmada

Até você criar juízo (AZEVEDO, 1998)

Em Dezenove poemas desengonçados, Azevedo mantém o jogo lúdico e plurissignificativo, outra característica marcante de sua produção:

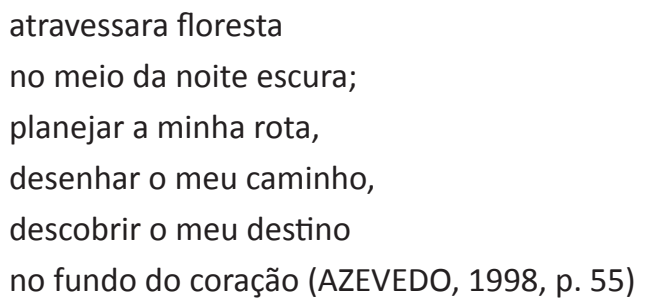

No texto Meu material escolar (2000), o escritor propõe uma nova maneira de ver ou realçar algo que faz parte do dia-a-dia de qualquer estudante, escrevendo poeticamente sobre os diversos materiais escolares utilizados na sala de aula, como a agenda, o apagador, o apontador, a borracha, o caderno, a lancheira, o pincel, dentre outros objetos. Eis alguns trechos:

\section{Lápis}

Quando escreve caprichado

Sua letra é bem formosa.

Mas quando escreve apressado,

A coisa fica horrorosa (AZEVEDO, 2000, p. 27).

\section{Pincel}

Não é pastel,

Nem tem chapéu.

Não vai pro céu, 
Nem anda ao léu.

Não tem anel,

Nem usa véu.

Termina com el,

Chama pincel! (AZEVEDO, 2000, p. 33)

Os versos possuem uma linguagem lúdica que instigam o leitor a participar do texto, tanto pelo aspecto temático como pela organização linguística por meio de ritmos e rimas (pastel/anel; chapéu/céu/léu; formosa/horrorosa), não se podendo esquecer a ilustração, sempre presente nestas obras, que, aliada à construção poética, as enriquece. Azevedo realiza um experimentalismo com a imagem visual, a qual provoca dinamicidade dos movimentos e cenas dos episódios, sendo responsável pela coesão e completude do poema. O autor é o próprio ilustrador de suas obras poéticas, com exceção de Não existe dor gostosa.

Em Feito bala perdida e outros poemas (2008), Ricardo Azevedo traz uma série de textos que rompem a fronteira entre o infantil e juvenil, desconstruindo a rubrica estabelecida pelo mercado editorial, visto que os textos poéticos trazem perguntas, reflexões e pontuações que perpassam o público jovem e o adulto. O escritor assinala "Não escrevi os poemas do livro pensando exclusivamente em jovens. Problemas sociais, restrições, drogas, dúvidas sobre a vida, conflitos, paixões, alienações, revoltas e contradições são assuntos que dizem respeito a todos nós" (AZEVEDO, 2008, p. 90). Pode-se dizer que os poemas contidos nessa obra provocam o leitor a pensar na sua condição enquanto sujeito que vive numa sociedade marcada por relações plurais, harmoniosas e agressivas.

O texto "Secretária eletrônica", por exemplo, diz sobre o distanciamento entre as pessoas, decorrente dos mecanismos tecnológicos e do sistema do capitalismo:

Você não ligou para o número 7654321

Mas estou aqui e posso atender

No sol na chuva no vento

Na terra no mar no ar

$\mathrm{Na}$ hora $\mathrm{H}$

Na hora do lobo

Na hora da onça beber água 
Na calmaria no carnaval

Antes e depois e durante o vendaval

Não deixe por favor recado nenhum

Venha ao vivo mesmo

Surja em carne e osso

Traga cabeça membros e o tronco

Onde um dia faz tempo escrevi

uma mensagem de amor você sabe como

apareça carregada de certezas atrozes e

dúvidas absolutas

bata à porta cheia de culpa prazer

espanto e segredo

Entre com feridas abertas ou cicatrizadas tanto faz

Não tenha medo. (AZEVEDO, 2008, p. 37)

O texto trata das relações humanas, o apelo por um contato não mecanizado e nem destituído do toque, da fala e do olhar. Independente das certezas, dúvidas e desconfortos, o eu-lírico propõe uma condição peculiar e um espaço que permita a comunicação entre os pares, incitando a proximidade física. Há a preocupação com o diálogo e a produção do sentido de viver entre as pessoas, visto que o homem se constitui a partir da relação com o outro.

Não diferentemente, o texto "Musculatura natural" aborda questões sobre as relações entre o homem e a sociedade, sobretudo no que se referem àquelas ligadas à manipulação do sujeito decorrente do apelo da mídia. O eu-lírico sugere a produção de pessoas que são movidas pelo desejo de se apropriarem dos produtos oferecidos pela indústria, preocupadas apenas com o exterior, distanciando-se das necessidades internas (psicológicas), o que, inevitavelmente, interfere na subjetividade do ser humano. :

Por fora: biceps botox liftings and piercings

Pele dura anestesiada por lipos silicones e grifes

Poses malhadas em performances hormônios anabolizantes

Óculos escuros em busca de luz diante do breu 
Por dentro: dúvida desejo culpa contradição e tédio

Medo no peito por conta de sentir tanta emoção

Controle de televisão espelhos computadores o tempo inteiro

Desesperanças e sonhos infiltrados na musculatura

Natural do coração (AZEVEDO, 2008, p. 14)

O eu-lírico apropria-se de um campo semântico específico do mercado ligado à produção da beleza física: bíceps, liftings e piercings e, ironicamente, usa a conjunção aditiva "and", com o intuito de provocar o leitor e remeter-lhe uma informação implícita. Ou seja, é provocativo ao evidenciar a influência da cultura alheia e a produção imposta pelos grupos de poder capitalista, somando-se a duas dimensões: interioridade versus exterioridade. Aparentemente, o sujeito apresenta uma "pele dura anestesiada".

A anestesia no texto de Azevedo possui duas interpretações, uma sugere a perda da sensibilidade, pois ela alivia uma dor, ou ainda refere-se ao uso da mesma durante algum procedimento cirúrgico, já que está inserida em um verso que cita esse tipo de prática. Desse modo, o eu-lírico fala de um corpo que não vive plenamente as reações naturais, mas condiciona-se ao desejo alheio, deixando-o intervir no curso da vida. Por consequência, há uma supressão de sua particularidade e sensibilidade, silenciando a sua idiossincrasia. Em outras palavras, o sujeito perde a sua identidade e a sua voz. Sendo assim, não determina suas escolhas em diversos âmbitos da vida, ao contrário, trata-se de um sujeito que corresponde aos anseios do capitalismo.

Sendo assim, deparamo-nos com um dilema de grande dimensão evidenciado nos versos de Ricardo Azevedo em "Musculatura natural", principalmente diante das informações instantâneas que moldam os desprevenidos. Isto posto, o homem entremeado à mídia e as convenções estéticas pode viver um repúdio das imposições do mercado, sentir uma angústia indefinida, manter-se aprisionado num corpo anestesiado ou livrar-se das mazelas advindas das imposições do cotidiano. A situação é de ambiguidade e contradição, marcada por uma luta interna. Então, a leitura de textos literários leva o leitor a repensar às circunstâncias da realidade que o cerca, de maneira que a experiência emocional advinda da relação entre o texto e o eu-lírico permite-lhe a reflexão crítica, afinal o pensamento remete-nos ao diálogo interior. 
A experiência humana não se reduz à imposição dos interesses alheios, porque o sujeito pode transitar em diferentes espaços no meio em que está inserido. Isso significa que ele pode questionar, mudar ou aceitar o que lhe é apresentado. Para tanto, é exigido ao homem o exercício constante de experimentar a vida na sua essência e não deixar-se anestesiar pelas convenções midiáticas. Ricardo Azevedo explora essa questão em "Questionário de cunho pessoal":

Quem dirige os passos que dou?

Quem sabe onde quero minhas mãos?

Quem determina os sonhos que tenho?

Quem decide o que enxergam meus olhos?

Quem escolhe as palavras da minha boca?

Quem controla o que sinto?

Quem domina os meus desejos?

Quem comanda minhas crenças?

Quem projeta e constrói minha estrada?

Quem autoriza as ideias dentro de mim

E governa, enfim, e faz um Eu

De um ato que deriva ser só meu? (AZEVEDO, 2008, p. 15)

O eu-lírico traz questões emblemáticas referentes à identidade e à constituição subjetiva do sujeito na sua relação com o outro, somando-se às forças invisíveis que determinam uma escolha ou outra no curso da vida. Isso se torna evidente, sobretudo no tempo em que estamos inseridos, pois os meios de comunicação são acessíveis a quase todas as comunidades do mundo. Deste modo, os textos evidenciam uma denúncia e uma reflexão.

Nessa mesma ordem, o texto "Ordenaram que eu pensasse o que quisesse", diz:

Ordenaram que eu pensasse o que quisesse

Exigiram que eu sentisse só prazer

Obrigaram-me a ser livre e independente

Decidiram meu destino e meu saber

Comandaram dentro de mim planos e sonhos 
E impuseram uma razão para eu viver. (AZEVEDO, 2008, p. 16)

A questão temática do poema nos remete ao pensamento de Zygmunt Bauman (1998) ao refletir sobre a experiência da liberdade no texto 0 mal-estar da pós-modernidade (1998). O estudioso assinala o jogo incerto, contraditório e inconclusivo sobre essa questão, pois ser livre

não significa não acreditar em nada: significa é acreditar em muitas coisas demasiadas para a comodidade espiritual de obediência cega; significa estar consciente de que há demasiadas crenças igualmente importantes e convincentes para a adoção de uma atitude descuidada ou niilista ante a tarefa da escolha responsável entre elas; e saber que nenhuma escolha deixaria o escolhedor livre da responsabilidade pelas suas consequências - e que, assim, ter escolhido não significa ter determinado a matéria de escolha de uma vez por todas, nem o direito de botar sua consciência para descansar.[...] a liberdade do livre, a individualidade do indivíduo são ameaçadas não apenas pelos detentores do poder. Estes últimos sustentam a liberdade individual como o laço que sustenta o homem enforcado (BAUMAN, 1998, p. 249-250).

Isto posto, notamos que Azevedo traz, em suas produções poéticas, questões contundentes e complexas ao leitor, a fim de mobilizá-lo a repensar na condição social e política. Conforme Bauman, a liberdade "é o nosso destino" (BAUMAN, 1998, p. 251), portanto, torna-se quase impossível desviar-se dela. Além disso, não há uma receita ou prescrição para deparar-nos com a liberdade. O sociólogo trata de duas questões relativas à modernidade: a social e psíquica. A primeira trata de "padrões, esperança e culpa. Padrões - que acenam, fascinam ou incitam, mas sempre se estendendo, sempre avançando adiante um pouquinho mais rápido do que os que vão no encalço" (BAUMAN, 1998, p. 91). A segunda trata da "identidade: da verdade de existência ainda não se dar aqui, ser uma tarefa, uma missão, uma responsabilidade" (BAUMAN, 1998, p. 91). Pontua, pois, o contraditório e a ambivalência de o sujeito ser e estar no mundo. Trata-se de um exercício constante e muito difícil, pois, ser moderno, segundo Bauman, é deparar-se com a impossibilidade de uma permanência fixa, ao passo que nem sempre ser moderno garante uma unidade psíquica, pois o movimento também pode provocar um ser dilacerado. Sendo assim, a literatura traz à tona questões 
relativas à modernidade.

Nas palavras de Azevedo "Liberdade", poeticamente, pode ser dita da seguinte maneira:

O I de liberdade é lúdico louco libertário

mas o i incomoda.

$\mathrm{O} \mathrm{b}$ de liberdade berra aos brados

mas o e envelhece e ensina

O r rompe regras

O d decide detonar duzentas e duas dezenas de

dúvidas

$\mathrm{O}$ a aspira autonomia

O outro d diz: depende!

Enquanto isso, o último e espia espera e expia

espantosamente. (AZEVEDO, 2008, p. 66)

O poema nos permite observar o emprego da repetição da conjunção mas nas primeiras estrofes, somando-se aos substantivos: liberdade e dúvida, como também de adjetivos significativos: lúdico, louco, libertário. Os verbos, por sua vez expressam movimentos diversos: incomodar, envelhecer, romper, detonar, aspirar, depender, espiar, esperar e expiar. Estes parecem ser possíveis caminhos para que o leitor posicione-se diante dessa tal liberdade que lhe é (im)posta. Todavia, o escritor não impõe uma verdade de forma didática, ao contrário, incita o leitor a viver a experiência da palavra.

Dessa maneira, observamos que a obra literária se realiza na intersecção do texto com o leitor e a concretização realizada pelo receptor, que converte a obra literária enquanto polo artístico em estético, pois a obra só se realiza na concretização produzida por ele. O sentido construído resulta das disposições do leitor e das estruturas do texto. Iser diz que:

Estas são de natureza complexa: embora estruturas do texto, elas preenchem sua 
função não no texto, mas sim à medida que afetam o leitor. Quase toda estrutura discernível em textos ficcionais mostra esse aspecto duplo: é ela estrutura verbal e estrutura afetiva ao mesmo tempo. $O$ aspecto verbal dirige a reação e impede sua arbitrariedade; o aspecto afetivo é o cumprimento do que é preestruturado verbalmente pelo texto. (ISER, 1996, p.51)

Nesse sentido, a descrição da interação entre texto e leitor, conforme Iser, deve, primeiramente, referir-se "aos processos constitutivos pelos quais os textos são experimentados na leitura" (ISER, 1996, p. 52), e à apreensão do efeito estético que provém do mundo. Como a existência do texto ficcional depende do efeito estimulador das leituras, compreendemos que os efeitos atualizados são produtos da experiência significativa do ato de ler. A interpretação deixa de ser apenas uma atividade de decifração, pois revela um potencial de sentido que advém do texto, proporcionado pelo ato da leitura, enquanto processo comunicativo. Os textos ficcionais e poéticos contêm elementos de indefinição, os quais permitem condições de comunicação entre o texto e o leitor, levando-o a fazer parte da produção e compreensão intencional da obra. Nas palavras de Zilberman:

A participação não se limita ao mero preenchimento dos vazios plantados pelo texto: como as orientações que recebe nunca estão plenamente definidas, dispersando-se ao longo do conjunto de palavras e sendo, às vezes, deixadas a seu critério, o destinatário é convidado a integrar-se no processo de constituição da obra, particularizando o processo de entendimento dela. (ZILBERMAN, 2001, p.51)

A participação efetiva do leitor nesse processo comunicativo forma a constituição do sentido e os elementos de indeterminação revelam condições favoráveis para a realização da comunicação, sobretudo quando o leitor experimenta outro universo, ainda por ele não vivenciado, apresentado no texto literário:

Só quando o leitor produz na leitura o sentido do texto sob condições que não lhe são familiares (analogizing), mas sim estranhas, algo se formula nele que traz à luz uma camada de sua personalidade que sua consciência descrevera. Tal tomada de consciência, no entanto, se realiza através da interação entre texto e leitor; é por isso que sua análise ganha primazia. (ISER, 1996, p. 98) 
Conforme Iser, na própria estrutura do texto há a presença do receptor, que o define como leitor implícito². O texto literário prevê a presença do leitor, elemento indispensável para a atualização do texto, e oferece papéis diversificados a seus possíveis receptores, definindo dois aspectos importantes: "o papel de leitor se define como estrutura do texto e como estrutura do ato" (ISER, 1996, p. 73). No que se refere à estrutura do texto, acreditamos em uma perspectiva de mundo criada pelo autor, ou seja, é na constituição do modo como é apresentado que se percebe tal perspectiva do emissor. $O$ texto não apresenta apenas uma perspectiva, mas compõe-se de um jogo de perspectivas que devem ser relacionadas para a concretização comum de referências. Dessa forma, fica estabelecida uma estrutura textual em que o leitor assume um ponto de vista que o permite integrar-se às perspectivas textuais.

Aliada à construção poética, a ilustração, indiscutivelmente, enriquece as obras de Azevedo, que realiza um experimentalismo com a imagem visual a qual provoca, colaborando pela coesão e completude do poema. Em sua vasta produção literária, Azevedo revela o experimentalismo com a linguagem, o uso do coloquialismo, disseminando-o por todo o texto, desprovido de artificialismo e, por isso mesmo, o eu-lírico estabelece uma cumplicidade com o leitor, convidando-o a participar da experiência literária. Na tessitura do texto, as palavras são instrumentos de poeticidade.

\section{Conclusão}

\footnotetext{
${ }^{2}$ No texto intitulado Seis caminhos pelos bosques da fiçcão (Companhia das Letrinhas, 1994), no primeiro capítulo "Entrando no bosque", Umberto Eco discorre sobre o ato da leitura, ressaltando a importância do leitor, partindo das noções de leitor empírico e de leitor modelo. Este último aproxima-se do leitor implícito de Iser, estrutura textual que prevê a presença de um receptor, estabelecendo pontos de vista, a fim de determinar o significado do texto, mas diferenciando-se do fictício - ao passo que o leitor-modelo de Eco é "uma espécie de tipo ideal que o texto não só prevê como colaborador, mas ainda procura criar [...] um conjunto de instruções textuais, apresentadas pela manifestação linear do texto." (1994, p. 15-22).
} 
O poder de nomear significava para os antigos hebreus dar às coisas a sua verdadeira natureza, ou reconhecê-la. Esse poder é o fundamento da linguagem, e, por extensão, o fundamento da poesia. (BOSI, 2000, p. 163)

A partir da leitura dos textos poéticos de Ricardo Azevedo, notamos que a poesia endereçada ao público infantil e juvenil traz algumas implicações que nos permitem (re) pensar uma série de questões, como o que é endereçado aos leitores crianças e aos jovens e o conteúdo/tema abordado pelo poeta. Os textos não são marcados pelo olhar ingênuo, recurso muito utilizado por alguns autores infanto-juvenis, ao contrário, há uma preocupação com o tempo histórico, político e psicológico, somando-se ao fato de que o poeta realiza um jogo com as palavras, pois se apropria dela e a transforma, atribuindo-lhe um sentido conotativo. Assim como um artesão, o poeta recria e lapida a palavra, doando-lhe um sentido novo e sendo ele mesmo o doador de sentido, como afirma Alfredo Bosi (2000).

Uma obra literária é constituída por uma teia infinita de outras obras, seja prosa ou poesia, pois "a obra é um mundo" (CANDIDO, 2004, p. 105). Deste modo, surgem as obras literárias e os escritores, que, por sua vez, perturbam o sossego do leitor crítico. Antonio Candido comenta que "todas as vezes, dizia Proust, que um grande artista nasce, é como se o mundo fosse criado de novo, porque nós começamos a enxergá-lo conforme ele o mostra" (CANDIDO, 2004, p. 105). Entendemos que o poeta e poesia estão sintonizados com o nosso tempo, talvez em um movimento atemporal, diluindo os tempos - presente, passado e futuro -, ou comungando-os por meio de paradoxos, antíteses e metáforas.

Isto posto, é notável a necessidade da poesia de comunicar algo ao seu leitor, visto que a obra "não é um produto fixo, unívoco ante qualquer público; nem este é passivo, homogêneo, registrando uniformemente o seu efeito. São dois termos que atuam um sobre o outro, e aos quais se junta ao autor" (CANDIDO, 2000, p. 74). Neste sentido, as palavras precisam chegar até o receptor num processo dialógico e interativo, uma vez que a literatura garante a sua existência quando estabelece uma relação com os leitores, porque "só vive na medida em que estes a vivem, decifrando, aceitando-a” (CANDIDO, 2000, p. 74).

Tendo em vista os aspectos analisados, percebemos o trabalho cuidadoso nos 
textos lidos, como construção literária, por se constituírem de uma linguagem particular e lúdica. As obras poéticas em questão apresentam um nível referencial e um nível simbólico, este marcado pelo uso constante de metáforas, metonímias, intertextualidade e outros recursos estilísticos, que contribuem para a construção de textos plurissignificativos. O modo como estes são organizados permitem ao leitor estabelecer a interação comunicativa com o eu-lírico, constituindo-se na "experiência estética", resultado do processo dialógico e do caráter emancipador do texto literário. A interação entre texto e leitor permite que o receptor viva experiências alheias e, se o poema possibilita-lhe vivenciar uma outra realidade que não a sua, ele pode romper com a práxis do cotidiano, experimentando uma nova visão da realidade.

Notamos em Azevedo um trabalho consciente com a linguagem literária, uma vez que ele utiliza recursos diversos, como: rimas, ritmo, figuras de linguagem, a valorização da linguagem oral, e, apropria ainda de outros fatores linguísticos e recursos estilísticos. Os exemplos citados evidenciam, de forma geral, alguns recursos expressivos do autor, que assinalam a sua escrita. Essa diversidade marca o experimentalismo com a linguagem e a proximidade com seu destinatário. Assim, a literatura cumpre o seu papel, falando das coisas da vida e do homem, dos sentimentos, dos medos, da curiosidade e do relacionamento humano.

Neste sentido, nas obras de Ricardo Azevedo, há vários planos na organização da linguagem, sendo que, esses diferentes planos se projetam um sobre o outro, permitindo, através do jogo de linguagem o desvelamento da obra, num sentido expressivo. Conforme Iser, "o discurso ficcional provoca efeitos quando convenções sociais tornam temas. Ao fazer uma seleção de convenções diferentes ele despragmatiza as convenções escolhidas" (ISER, 1996, p. 115). Daí a provocação de uma leitura vertical, invocada pela organização horizontal, permitindo ao leitor efeitos antes não experimentados.

Em síntese, podemos considerar que os textos poéticos desempenham um papel humanizador, sobretudo ao se referirem a temas relativos às questões humanas, aos sentimentos, às emoções, às influências midiáticas e mercadológicas, à construção e constituição da subjetividade, à postura crítica do sujeito ante a invasão e a tentativa de manipulação dos desejos. Os textos recorrem ao tempo imediato, atemporal, subjetivo, e provocam no leitor reflexões sobre a existência humana. Assim, observamos que os textos poéticos de Ricardo Azevedo rompem com a delimitação infantil, juvenil e adulta, pois retomam a vida 
na sua essência. No entanto, nossas pontuações não se encerram nas considerações aqui realizadas, e salientamos que há outras possibilidades de leitura, afinal, parodiando Candido, a poesia é um mundo e este se faz perceber através dos versos, rimas, estrofes e ritmos.

\section{Referências Bibliográficas}

AGUIAR, Vera Teixeira de; CECCANTINI, João Luís (orgs.). Poesia infantil e juvenil brasileira: uma ciranda sem fim. Assis: ANEP; São Paulo: Cultura Acadêmica, 2012.

AZEVEDO, Ricardo. A Casa de meu avô. Projeto gráfico e ilustração do autor. São Paulo: Cia Melhoramentos, 1986.

. Dezenove poemas desengonçados. Projeto gráfico e desenhos do autor. São Paulo: Ática, 1997.

. A Casa de meu avô. Projeto gráfico e ilustração do autor São Paulo: Ática, 1998.

(Revisto e redesenhado)

. Meu material escolar. Ilustração do autor. São Paulo: Quinteto, 2000.

. Poemas com sol e com som. Coletânea com diversos autores. Melhoramentos.

Coedition Latino americana, 2000.

2001.

O livro de papel. Projeto gráfico e desenho do autor. São Paulo: Ed. Do Brasil,

. Não existe dor gostosa. Ilustração de Mariana Massarani. São Paulo: Companhia das Letrinhas, 2003.

. "A didatização e a precária divisão de pessoas em faixas etárias: dois fatores de (não) formação de leitores". In: PAIVA, Aparecida. MARTINS, Aracy. et.al. Literatura e Letramento - Espaços, suportes e interfaces. O jogo do livro. Belo Horizonte: Editora Autêntica, 2003.

. Ninguém sabe o que é um poema.llustração do autor. São Paulo: Ática, 2005.

. Feito bala perdida. São Paulo: Ática, 2008.

BAUMAN, Zygmunt. O mal estar da pós-modernidade. Tradução de Mauro Gama e Claudia Martinelli Gama. Rio de Janeiro: Zahar, 1998.

BOSI, Alfredo. O ser e o tempo da poesia. São Paulo: Companhia das Letras, 2000.

CANDIDO, Antonio. "A literatura e formação do homem". In: Ciência e cultura. São Paulo, v.24, n.9, p.803-809, set.1972.

. Vários escritos. 3a ed. São Paulo: Livraria duas cidades, 1995.

. Literatura e sociedade: estudos de teoria e história literária. 8a edição. São Pau-

lo: T. A. Queiroz, 2000.

. O discurso e a cidade. 3a edição. São Paulo: Duas cidades, 2004. 
COELHO, Nelly Novaes. Dicionário crítico da literatura infantil/juvenil brasileira. 5.ed. rev. São Paulo: Cia. Editora Nacional, 2006. Panorama histórico da literatura infantil/juvenil: das origens indo-europeias ao Brasil contemporâneo. 4. ed. rev. São Paulo: Ática, 1991.

ECO, U. Seis passeios pelos bosques da ficção. Tradução HildegardFeist. São Paulo: Companhia das Letras, 1994.

HUNT, Peter. Crítica, teoria e literatura infantil. Trad. Cid Knipel Moreira. São Paulo: Cosac Naify, 2010.

ISER, W. O ato da leitura: uma teoria do efeito estético. Tradução JohannesKretscmer. Vol. 1. São Paulo: Editora 34, 1996.

$O$ ato da leitura: uma teoria do efeito estético. Tradução JohannesKretscmer. Vol.2. São Paulo: Editora 34, 1999. . Teoria da ficção: indagações à obra de Wolfgang Iser. João Cezar de Castro (Org.). Tradução Bluma Waddington et al. Rio de Janeiro: EDUERJ, 1999. A indeterminação e a resposta do leitor na prosa de ficção. Tradução Maria Ângela Aguiar. Cadernos do Centro de Pesquisas Literárias da PUCRS. Porto Alegre: Publicação do Curso de Pós-graduação em Letras, volume 3, Número 2, março de 1999. LAJOLO, Marisa. ZILBERMAN, Regina. Literatura infantil brasileira: história \& histórias. São Paulo: Ática, 1984.

MARTHA, Alice Áurea Penteado. "Pequena prosa sobre versos". In: AGUIAR, Vera Teixeira de; CECCANTINI, João Luís (orgs.). Poesia infantil e juvenil brasileira: uma ciranda sem fim. Assis: ANEP; São Paulo: Cultura Acadêmica, 2012. (45 - 73)

ZILBERMAN, Regina. A Literatura infantil na escola. São Paulo: Global, 1981. Fim do livro, fim dos leitores? São Paulo: Senac, 2001. (Ponto Futuro; 3) 